\title{
Immunotherapy, immunochemotherapy and chemotherapy for American cutaneous leishmaniasis treatment
}

\author{
Imunoterapia, imunoquimioterapia e quimioterapia no \\ tratamento da leishmaniose tegumentar americana
}

\author{
Wilson Mayrink ${ }^{1}$, Ana Cristina de Carvalho Botelho ${ }^{1,3}$, Paulo Araújo Magalhães ${ }^{6 \dagger}$, \\ Sebastião Mariano Batista ${ }^{1 \dagger}$, Antonio de Oliveira Lima ${ }^{7 \dagger}$, Odair Genaro ${ }^{1 \dagger}$, Carlos Alberto da Costa ${ }^{4}$, \\ Maria Norma de Melo ${ }^{1}$, Marilene Susan Marques Michalick ${ }^{1}$, Paul Williams ${ }^{1}$, \\ Magno Dias ${ }^{2}$, Waleska Teixeira Caiaffa ${ }^{8}$, Evaldo do Nascimento ${ }^{1}$ \\ and George Luiz Lins Machado-Coelho²
}

\begin{abstract}
The first choice of treatment for American cutaneous leishmaniasis is the pentavalent antimonial drug. Although it has been shown that this treatment is mostly effective and indicated, some disadvantages should be taken into account such as side effects, long term treatment inconveniences and counter-indication for patients suffering from cardiopathy, nephropathy; yet, aging, pregnancy and other conditions. With the advent of the vaccine anti-American cutaneous leishmaniasis as a prophylactic measure, studies on therapy using the vaccine associated or not with other drugs have been performed by many investigators and it is currently among the alternative treatments and prevention measures for American cutaneous leishmaniasis. In conclusion, the association between antimony and vaccine (immunochemotherapy) showed the same cure rate when compared with the standard treatment (100\%) and it was also able to reduce the salt volume in 17.9\% and treatment length from 87 to 62 days, decreasing side effects.
\end{abstract}

Key-words: American cutaneous leishmaniasis. Treatment. Immunotherapy.

\section{RESUMO}

O tratamento de primeira escolha para leishmaniose tegumentar americana é o antimonial pentavalente. Embora este tratamento seja na maioria das vezes efetivo e indicado, devem ser consideradas as desvantagens tais como efeitos colaterais, longa duração do tratamento e contra-indicação para cardiopatas, nefropatas, idosos, grávidas e outras condições. Com o advento da vacina antileishmaniose tegumentar americana para fins profiláticos e terapêuticos, associando-a ou não a outros fármacos, muitas pesquisas têm sido desenvolvidas, sendo a vacina a principal entre os atuais recursos no tratamento e prevenção da leishmaniose tegumentar americana. Em conclusão, a associação do antimônio com a vacina (imunoquimioterapia) apresentou o mesmo índice de cura em relação ao tratamento padrão (100\%), e ainda reduziu o volume do sal em 17,9\% e o tempo de cura significativamente, de 87 para 62 dias; conseqüentemente, reduzindo os efeitos colaterais.

Palavras-chaves: Leishmaniose tegumentar americana. Tratamento. Imunoterapia.

\footnotetext{
1. Departamento de Parasitologia do Instituto de Ciências Biológicas da Universidade Federal de Minas Gerais, Belo Horizonte, MG. 2. Departamento Farmácia da Escola de Farmácia da Universidade Federal de Ouro Preto, Ouro Preto, MG. 3. Centro Pesquisas René Rachou da Fundação Oswaldo Cruz, Belo Horizonte, MG. 4. Departamento de Parasitologia da Faculdade de Farmácia da Universidade Federal de Minas Gerais, Belo Horizonte, MG. 5. Departamento de Ciências Biológicas da Universidade Federal de Ouro Preto, Ouro Preto, MG. 6. Superintendência de Campanha Sanitária do Ministério da Saúde. 7. Fundação Ataulfo Paiva, Belo Horizonte, MG. 8. Departamento de Medicina Preventiva e Social da Faculdade de Medicina da Universidade Federal de Minas Gerais, Belo Horizonte, MG.

In memoriam.

Supported by FAPEMIG, SMSC, CNPq, UFMG, CISMRC

Address to: Dr. Wilson Mayrink. Rua Equador 140/201, Bairro São Pedro, 30330-390 Belo Horizonte,MG, Brasil

Tel: $55313287-3038$

e-mail: wilsonmayrink@uol.com.br

Recebido para publicação em 2/7/2004

Aceito em 23/11/2005
} 
Leishmaniasis is a disease caused by several digenetic protozoan species of the genus Leishmania, which affect humans and different domestic and sylvatic animal species. The disease may arise in different forms and the most important are: American visceral leishmaniasis (AVL) or American kala-azar and American cutaneous leishmaniasis (ACL). The latter, is primarily a disease that affects sylvatic animals. Leishmaniasis is transmitted to humans through the female bite of female haematophagous insect vectors of the genus Lutzomyia, which are known, in Brazil, as 'biriguii', 'mosquito-palha' or 'cangalhinha'.

ACL is a polymorphic disease of skin and mucous membranes with single or multiple ulcerative lesions (simple cutaneous form), nodular lesions (diffuse form) or mucocutaneous lesions (mucocutaneous form), affecting nasopharynx regions simultaneously with or just after an initial cutaneous infection. Such variation is closely related to the patient's immunological status and the Leishmania species involved. ACL constitutes an important health problem mainly because of its difficult prevention. The World Health Organization (WHO) estimates around 1-2 million annual new cases annually ${ }^{78}$.

Up to 1912, leishmaniasis treatment had been unsatisfactory. Row $^{62}$ reported results on the curative properties of promastigote forms, from Leishmania culture, used as a vaccine in the treatment for Oriental sore; this therapy was then abandoned due to a new systemic treatment with antimonial drugs introduced that year by the Brazilian physician Gaspar Vianna ${ }^{76}$. This investigator used emetic tartar at $1 \%$, which proved to be more efficient than the vaccine.

Emetic tartar has been the only therapeutic alternative for leishmaniasis for many years and because of its toxicity, administration difficulties and unsatisfactory efficacy (frequent recurrences), it was, at last, replaced with pentavalent antimonial drugs $\mathrm{s}^{2125}$. Despite its counter-indications for elderly patients and other conditions, such as cardiopathy, nephropathy and pregnancy, the pentavalent antimonial drug represents the standard therapy for leishmaniasis nowadays.

Since the introduction of antimonial drugs for leishmaniasis therapy, which have also been shown to produce divergent results 381718202426293344495152606365667074 , several studies have been carried out in order to establish the best therapeutic plan.

With the advent of the ACL vaccine for prophylactic aims, idealized by Gomes ${ }^{23}$, Pessoa and Pestana ${ }^{55}$, modified by Mayrink et $\mathrm{al}^{3536}$, and proved by Antunes et $\mathrm{al}^{4}$ and Armijos et al ${ }^{5}$, its therapeutic use has been under study, whether alone or associated with other drugs; and it has also been regarded as one of the current treatments, as well as one of the available prophylactic measures for $\mathrm{ACL}^{1422} 28353943$.

Reports on the use of chemotherapy associated with immunotherapy have shown considerable efficacy in some cases of diffuse leishmaniasis ${ }^{377172}$.
Immunotherapy combined with the use of BCG, first performed by Convit ${ }^{14}$, showed cure rates and treatment length comparable with those obtained through standard treatments with Glucantime ${ }^{\circledR}$.

The present work was aimed at: 1) using immunotherapy in ACL patients for whom antimonial drugs are restricted and; 2) using immunotherapy combined with chemotherapy (immunochemotherapy), since we observed that an immunological stimulus associated with a chemotherapy treatment leads to a reduction in antimony volume and treatment period. This complex provides substantial benefits to the patient, reducing their visits to the outpatient facility, thus, diminishing ambulatory expenses, among many other advantages, when compared to the standard therapy. This process is described in detail in the present work.

The current work is aimed at evaluating the clinical effects among different therapeutic plans and not at assessing the immunological aspects involved in such responses, which has been widely studied by other investigators 7101216194247585975 .

\section{PATIENTS AND METHODS}

Population studied. A sample of 542 patients diagnosed with ACL, including males and females aged over five years old (Table 1), was randomly selected in a open assay from a group of subjects attending the Outpatient Facility Paulo Araújo de Magalhães in Caratinga, Minas Gerais. The present investigation and the protocols comply with the Research Ethics Committee of Instituto de Ciências Biológicas of Universidade Federal de Minas Gerais-ICB/UFMG.

Diagnosis. Individuals with typical cutaneous lesions were clinically diagnosed as being carriers of ACL. Clinical diagnosis was confirmed through positive parasitological examination and/or Montenegro skin test (MT).

Parasitological examination. Parasitological examination was confirmed by the presence of amastigote forms of the parasite in skin biopsies from the lesions. The examination was carried out by compressing the tissue from biopsy between two histological slides, after removing blood excess blood with filter paper. The material collected was fixed in methanol, Giemsa stained and, then, examined under light optical microscopy (magnification 1,000X).

Montenegro test. Montenegro antigen was produced under sterile conditions from cloned promastigote cultures of I-III-D Leishmania (Leishmania) amazonensis, which were killed, sonicated and kept in merthiolate solution at 1:10,000 $0^{40}$. A volume of $0.1 \mathrm{~mL}$ of the antigen with $40 \mu \mathrm{g} / \mathrm{mL}$ of nitrogen ${ }^{38}{ }^{41}$ was injected into intradermal layer in the inner side of the arm. Positivity was indicated after nodule formation, 48 hours post test, without considering erythematous areas. 


\begin{tabular}{|c|c|c|c|c|c|c|c|c|c|c|c|}
\hline Groups & $\begin{array}{c}\text { S Therapeutic } \\
\text { scheme }\end{array}$ & $\begin{array}{c}\text { Number of } \\
\text { cases }\end{array}$ & $\begin{array}{c}\text { Male } \\
\text { gender } \\
(\%)\end{array}$ & $\begin{array}{l}\text { Age average } \\
\text { (years) }\end{array}$ & $\begin{array}{c}\text { Malnutrition } \\
\text { (\%) }\end{array}$ & $\begin{array}{c}\text { Disease } \\
\text { period } \\
\text { (month) }\end{array}$ & $\begin{array}{l}\text { Number } \\
\text { of lesions }\end{array}$ & $\begin{array}{c}\text { Lesion } \\
(\mathrm{cm})\end{array}$ & $\begin{array}{l}\text { MT } \\
(\mathrm{cm})\end{array}$ & $\mathrm{MT}+(\%)$ & $\begin{array}{c}\text { Positive } \\
\text { parasitological } \\
\text { exam (\%) }\end{array}$ \\
\hline 2 & QT 0.5 & 29 & 58.6 & 23.4 & 13.8 & 2.1 & 1.1 & 2.6 & $7.8^{*}$ & 82.8 & 92.9 \\
\hline 1 & QT 1.0 & 39 & 61.4 & 30.6 & 4.7 & 2.4 & 1.3 & 4.9 & 5.2 & 81.8 & 84.1 \\
\hline 3 & IT serial & 53 & 64.2 & 33.2 & 9.6 & $5 . .9$ & 1.2 & 3.1 & 2.8 & 73.1 & 88.7 \\
\hline 1 & QT 1.0 & 35 & 51.4 & 30.8 & $2 . .9$ & 4.2 & 1.3 & 3.2 & 3.9 & 85.3 & 87.9 \\
\hline 4 & QT 1.0 & 38 & 50.0 & $21.5^{*}$ & NR & 2.4 & 1.4 & 3.6 & 3.7 & 89.2 & 89.5 \\
\hline 1 & QT 1.0 & 49 & 59.2 & 31.0 & NR & 2.7 & 1.3 & 4.6 & 5.3 & 83.7 & 93.6 \\
\hline 5 & IQT 0.5 & 47 & 44.7 & 27.3 & 14.9 & $2 . .3$ & 1.3 & 3.6 & 7.1 & 85.1 & 85.1 \\
\hline 1 & IQT 1.0 & 44 & 61.4 & 30.6 & 4.7 & 2.4 & 1.3 & 5.0 & 5.2 & 81.8 & 84.1 \\
\hline 6 & colliquation & 47 & 68.1 & 27.7 & 14.9 & 3.0 & 1.4 & 3.4 & 4.8 & 72.3 & 87.0 \\
\hline 7 & IT and BCG monthly & 58 & 70.7 & 26.0 & 7.0 & 3.3 & 1.4 & 3.7 & 5.6 & 81.0 & 89.7 \\
\hline 8 & BCG monthly & 13 & 53.8 & 26.8 & 15.4 & 3.6 & 1.2 & 7.5 & 7.2 & 84.6 & 76.9 \\
\hline 9 & IT monthly & 12 & 33.3 & 28.1 & 16.7 & 2.9 & 1.1 & 5.9 & 7.8 & 100.0 & $58.3^{*}$ \\
\hline 1 & QT 1.0 & 78 & 61.5 & 30.8 & 14.1 & 2.7 & 1.3 & 4.7 & 5.2 & 84.6 & 94.8 \\
\hline \multicolumn{2}{|l|}{ Total } & 542 & 59.3 & 28.6 & 10.8 & 5.3 & 1.3 & 4.1 & 5.2 & 82.4 & 89.0 \\
\hline
\end{tabular}

QT 1.0: Standard Group, * Significant difference when compared with standard group. MT: Montenegro Test.

Vaccine. The vaccine was prepared by the Laboratory of Leishmaniasis of the Department of Parasitology, ICB - UFMG, using dead promastigote forms of Leishmania (Leishmania) amazonensis, strain IFLA/BR/67/PH8, in accordance with the technique proposed by Mayrink et al ${ }^{36}$ under quality control patterns of the Pharmacy School of UFMG.

BCG. BCG, used as coadjutant (BCG, Calmete Bacillus Guerin da Fundação Ataulfo Paiva, Rio de Janeiro, RJ), was reconstituted by dilution in $1 \mathrm{~mL}$ solution $(100 \mu \mathrm{g} / \mathrm{mL})$.

Antimoniate $\mathbf{N}$-methyglucamine. The pentavalent antimonial $\left(\mathrm{Sb}^{\mathrm{v}}\right)$ used here was $\mathrm{N}$-methyglucamine (Glucantime®; Rhodia, São Paulo, Brazil), comprising 85mg pentavalent antimonial per $\mathrm{mL}$.

Therapy. Group 1 (Standard treatment) Chemotherapy I (QT 1.0). This group consisted of 245 patients treated with Glucantime ${ }^{\circledR}$. It was slowly administered through intramuscular route, at a daily dose of $1 \mathrm{~mL} / 5 \mathrm{~kg}$ body weight, without exceeding $10 \mathrm{~mL} /$ day, for 10 days. After a 10-day interval, this treatment was repeated. This period of 10 days of treatment plus 10 days of interval was named one series of treatment and it is carried out, and repeated until complete clinical cure of the patients is achieved.

Group 2. Chemotherapy II (QT 0,5$)$. This group comprised 29 patients under treatment with Glucantime $\AA$, at a daily dose of $0.5 \mathrm{~mL} / 5 \mathrm{~kg}$ body weight. The administration was performed as described above and the maximum daily dose did not exceed $5 \mathrm{~mL} /$ day.

Group 3. Serial immunotherapy (IT serial): in this group, 53 patients, underwent subcutaneous administration of the vaccine (nitrogen total concentration: $360 \mu \mathrm{g} / \mathrm{mL}$ ) administered to the top outer forearm, according to the method proposed by Mayrink ${ }^{35}$ as follows: first day- $100 \mathrm{~mL}$; second day- $200 \mu \mathrm{L}$; third day- $300 \mu \mathrm{L}$; fourth day- $400 \mu \mathrm{L}$ and from the fifth to the tenth day- $500 \mu \mathrm{L}$.

After a 10-day interval, daily doses of $500 \mathrm{~mL}$ were administered.
Group 4. Immunochemotherapy I (IQT 1,0). In this group, 38 patients were administered anti-ACL vaccine through subcutaneous route, as described for Group 3, simultaneously with Glucantime ${ }^{\circledR}$ through intramuscular route at a dose of $1 \mathrm{~mL} / \mathrm{kg}$ body weight, as used for Group 1 .

Group 5. Immunochemotherapy II (IQT 0.5). A group of 47 patients were given subcutaneous anti-ACL vaccine, as described for Group 3, simultaneously with Glucantime ${ }^{\circledR}$ through intramuscular route at a dose of $0,5 \mathrm{~mL} / 5 \mathrm{~kg}$ body weight, as used for Group 2.

Group 6. Colliquation (BCG + Glucantime $\left.{ }^{\circledR}\right)$. A group of 47 patients were administered $100 \mu \mathrm{g}$ intradermal BCG after 15 to 20 days of stimulation with the onset of colliquation, Glucantime ${ }^{\circledR}$ was used at a dose of $1 \mathrm{~mL} / 5 \mathrm{~kg}$ body weight, as described for Group 1.

Group 7. Monthly immunotherapy with BCG $(100 \mu \mathrm{g})$ (IT and BCG monthly). Fifty-eight patients were submitted to monthly intradermal doses of an association of $0.6 \mathrm{~mL}$ of vaccine with $100 \mu \mathrm{g}$ BCG until clinical cure was achieved, without exceeding a period of five months under treatment.

Group 8. Monthly BCG. Thirteen patients were treated with monthly intradermal doses of $100 \mu \mathrm{g}$ of $\mathrm{BCG}$, administered into the deltoid muscle.

Group 9. Monthly immunotherapy (IT monthly). In this group, 12 patients were treated with monthly doses of $0.6 \mathrm{~mL}$ vaccine.

Therapeutic failure. It should be noted that each therapeutic plan was maintained until complete clinical cure was achieved; if cure was not effected after two series, the plan was, then, substituted for the standard therapy (serial chemotherapy with Glucantime $\left.{ }^{\circledR}\right)$.

Cure criterion. The cure criterion was clinical, i.e., total healing of cutaneous lesions and epithelization of the skin.

Statistical analysis. Variance analysis for treatment period analysis, adjusted by age, disease period, and MT area was used ${ }^{73}$. A significance level of $95 \%$ was taken into account. 


\section{RESULTS}

A total of 542 patients with positive ACL diagnosis were divided into 9 treatment groups. The demographic and clinical characteristics of the groups studied are shown in Table 1. The frequency of male gender was $59.3 \%$ and the mean age was 28.6 years old (ranging from 5 to 86 years old). No significant relationship regarding the gender and age of the patients was found among the groups tested, including the standard group. Malnutrition, defined by body mass index (BMI = weight/ height ${ }^{2}$ ), was observed in $10.8 \%$ of the patients, which was shown to be similar for all the groups under study (Table 1).

The period of ACL disease, defined as the time taken between the initial observation of the lesion, reported by the patient, and clinical diagnosis, ranged from 10 days to 43.4 months with an average of 5.3 months. The number of lesions varied from 1 to 3 , and their mean diameter was $4.1 \mathrm{~cm}$. The mean MT area, which was showen to be positive in $82.4 \%$ of patients, was $5.2 \mathrm{~cm}$. The parasitological exam was positive in $89 \%$ of patients. No relationship between the number of lesions, disease period, and area of ulcers was observed among patients (Table 1).

The treatment period of the groups under study and the volume of antimony necessary to achieve cure are shown in Table 2.

The average length of treatment in days for clinical ACL cure was: 94.6 for Group 1; 81.0 for Group 2; 172.8 for Group 3; 64.7 for Group 4; 105.5 for Group 5; 91 for Group 6; 177.2 for Group 7; and 159.5 and 226.7 days for Groups 8 and 9, respectively.

The therapy plans used in Groups 1, 4, 5, and 6 achieved clinical cure in $100 \%$ of the patients with varying periods (days) of 94, 64, 105 and 91 days, respectively.

Group 3, under immunotherapy, showed $98.1 \%$ of cured patients, despite its increased treatment length when compared with the standard group.

The average number of series, comprising all therapies, ranged from 3.3 to 11.3 .

\begin{tabular}{|c|c|c|c|c|c|c|c|}
\hline Groups & Therapy & $\begin{array}{l}\text { Number of patients/ } \\
\text { Number of cured cases }\end{array}$ & $\begin{array}{c}\text { Cure } \\
\text { percentage }\end{array}$ & $\begin{array}{c}\text { Mean number } \\
\text { of series }^{\mathrm{a}}\end{array}$ & $\begin{array}{c}\text { Reduction of } \\
\text { SB }^{\mathrm{v}} \text { volume (\%) }\end{array}$ & $\begin{array}{c}\text { Number of series of } \\
\text { Glucantime in case resistance }\end{array}$ & $\begin{array}{c}\text { Mean time of treatment } \\
\text { until cure (day) }\end{array}$ \\
\hline 2 & QT 0.5 & $29 / 29$ & 100.0 & 4.2 & 50.0 & - & 82.2 \\
\hline 1 & QT 1.0 & $39 / 39$ & 100.0 & 4.6 & 100.0 & - & 94.6 \\
\hline 3 & Serial & $53 / 52$ & 98.1 & 8.7 & 17.9 & 7.0 & 172.8 \\
\hline 1 & T 1.0 & $35 / 35$ & 100.0 & 4.2 & 33.3 & - & 82.5 \\
\hline 4 & T 1.0 & $38 / 38$ & 100.0 & $3.3^{*}$ & 7.7 & - & 64.7 \\
\hline 1 & T 1.0 & $49 / 49$ & 100.0 & 4.8 & 100.0 & - & 94.8 \\
\hline 5 & T 0.5 & $47 / 47$ & 100.0 & 5.4 & 100.0 & - & 105.5 \\
\hline 1 & T 1.0 & $44 / 44$ & 100.0 & 4.8 & 100.0 & - & 94.6 \\
\hline 6 & Colliquation & $48 / 48$ & 100.0 & 4.7 & - & - & 91.0 \\
\hline 7 & IT and BCG monthly & $58 / 27$ & $46.6^{*}$ & $8.9^{*}$ & & 3.6 & $177.2^{*}$ \\
\hline 8 & BCG monthly & $13 / 4$ & $38.8^{*}$ & $8.0^{*}$ & & 4.2 & $159.5^{*}$ \\
\hline 9 & IT monthly & $12 / 3$ & 25.0 & $11.3^{*}$ & & 4.3 & $226.7^{*}$ \\
\hline 1 & T 1.0 & $78 / 78$ & 100.0 & 4.4 & & - & 86.5 \\
\hline Total & & 542 & 89.9 & 5.7 & - & 3.9 & 113.1 \\
\hline
\end{tabular}

1 QT 1.0: Standard Group, * Significant difference when compared with standard group. ${ }^{a}$ Adjusted by disease time, lesion area and area of Montenegro test.1/ QT 1.0: Glucantime 1,0mL/5kg body weight Standard Therapy, 2/ QT 0.5: Glucantime 0,5mL/5kg body weight, 3/ IT serial: Vaccine serial, 4/ IQT 1.0: Vaccine + Glucantime 1mL, 5/ IQT 0.5: Vaccine + Glucantime 0,5mL, 6/ Colliquation: BCG + Glucantime, 7/ BCG IT montly: BCG+ vaccine monthly, 8/ Monthly BCG, 9/Vaccine Monthly immunotherapy

\section{DISCUSSION}

No individual aspect of the patients or possible correlations with age, gender, nutritional status and number of lesions was shown to have a significant difference through variance analysis among the groups under study.

Based on these results, immunotherapy (Group 3) may be an alternative treatment for those patients for whom Glucantime ${ }^{\circledR}$ is not indicated.

By associating the vaccine with the standard application of Glucantime ${ }^{\circledR}$ (Group 4), a reduction in the volume of antimony (17.9\%) and treatment length for clinical cure (from 94.6 to 64.7 days) was observed, when compared with the standard treatment (Group 1).

In the case of immune-stimulation with vaccine, an enhancement in interferon $\gamma$ and interleukin 2 (IL-2) production was observed potentializing the response type Th1 by activating macrophages through INF $\gamma$ production, in agreement with that shown by other investigators ${ }^{45}$. This leads to the destruction of parasites by increasing oxygen radical levels, mainly nitric oxide. Furthermore, interferon ã induces macrophages to produce IL 12, which acts on lymphocytes and "Natural Killer" (NK) cells, potentializing the immune response. These are ongoing findings in our works (data not shown).

When meglumine antimoniate volume was diminished by $50 \%$ to treat Group 2 patients, treatment length was shown to be as short (81 days) as that for Group 1, and cure rates were the same in both groups.

Association between the antimonial drug and immunotherapy (Group 4) showed a significant reduction in treatment length and also approximately 18\% decrease in antimony volume, when compared with Group 1. 
Immunotherapy associated with half the dose of meglumine antimoniate (Group 5) increased treatment length, in contrast, antimony volume was decreased by $33.3 \%$, consequently, minimizing the side effects caused by Glucantime ${ }^{\circledR}$.

Group 6, receiving BCG for 15 to 20 days before chemotherapy, showed a reduction of $7.7 \%$ in antimony volume, with no statistical significance, and a slight increase in treatment length for clinical cure in relation to Group 1.

The therapy comprising BCG and monthly immunotherapy (Groups 8 and 9) did not contribute to a reduction in the treatment period when compared with the standard treatment.

Considering the fact that other investigators only achieved 50.8\% of clinical cure at a dose of $20 \mathrm{mg} / \mathrm{kg} / \mathrm{day}$, either through intramuscular or intravenous route, for 20 days $^{60}$, it should be noted that our service achieved a cure rate of $100 \%$ with Glucantime ${ }^{\circledR}$ therapy (Group 1). Literature data has shown that treatment with meglumine antimoniate for 10 or 20 days, at a dose of $20 \mathrm{mg} / \mathrm{kg} /$ day, achieves clinical cures of $61 \%$ and $67 \%$, respectively ${ }^{33}$.

Similar results to those obtained here with the standard treatment here (Group 1) were also achieved by our research team in $2002^{31}$ while treating 29 patients from the municipality of Araçuaí, State of Minas Gerais. These patients had no indication for treatment with the standard antimonial therapy, mainly due to the presence of electrocardiographic alterations (17), antimony allergy (4), pregnancy (6) and nephropathy (2). Among these patients, 10 underwent immunochemotherapy and another 19 immunotherapy. The cure rate proved to be $100 \%$ and the mean number of series up to clinical cure was 2.3 (ranging from 1 to 4 series), while for immunochemotherapy, this was 2.47 series, with similar variation for both therapies.

Considering that antimony may produce side effects, a concentration reduction in ACL treatments is quite important. However, appropriate therapy should be carried out in order to diminish likely recurrences of the mucous form ${ }^{61}$ as well as other kinds of recurrences that have been frequently

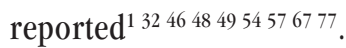

Considering the broad range of therapies for ACL, there is no consensus among those aimed at seeking a reduction in the side effects of pentavalent antimonial drugs, there is no consensus. Azeredo-Coutinho and Mendonça ${ }^{6}$ compared two therapies: a continuous plan, as recommended by $\mathrm{WHO}^{78}$, and a serial one. These investigators concluded that the cure rate obtained with the intermittent treatment (serial) proved to be significantly higher than that with the continuous plan. The cure criterion was defined by complete skin epithelization observed up to three months after the end of treatment. Surprisingly, the follow-up of the patients was greatly superior when they were submitted to the serial treatment. Most of the patients under continuous treatment did not attend the Outpatient Facility throughout the complete period of treatment. Such data corroborate our findings ${ }^{34}$ concerning serial treatment, although there are divergences regarding clinical cure criteria. In the present study serial treatment was maintained until complete healing of the cutaneous lesions and the use of only three series was not followed.
Despite Machado-Coelho's ${ }^{31}$ reports on resistance, have been quite rare cases of resistance to Glucantime in chemotherapy treatment have been quite rare in the municipality of Caratinga. Patients from other regions usually seek this Out Patient Facility due to previous failed treatments, performed in other localities.

In the case of ACL recurrence, patients attended at our service are recommended to return to the Outpatient Facility of Caratinga, as well as those from other regions, who are addressed by different health units due to the popular knowledge on treatments of cutaneous lesions provided by this ambulatory in Caratinga. Some patients from different regions, who underwent the treatment, indicated by the $\mathrm{WHO}^{78}$ ( $15 \mathrm{mgSb} / \mathrm{kg} /$ day for 20 days and maximum daily dose of $15 \mathrm{~mL} /$ day), sought our services due to disease recurrence or intolerance to the salt. Based on the WHO therapy, cure criterion is the complete healing of cutaneous lesions observed up to 3 months after the treatment end, which lasts 20 days with or without complete epithelization. Eight, from among these patients, sought our ambulatory and underwent further treatment with the antimony in a serial plan (a 10-day treatment + a 10-day rest) associated with the vaccine $(0,5 \mathrm{~mL} /$ day $)$, simultaneously administered with Glucantime ${ }^{\circledR}$. The Glucantime ${ }^{\circledR}$ daily dose was $1 \mathrm{~mL} / 5 \mathrm{~kg}$ body weight without exceeding $10 \mathrm{~mL} /$ day. This treatment varied from 2 to 4 series, which was only interrupted with clinical cure.

Several investigators have reported the side effects of Glucantime ${ }^{\circledR}$ used in different therapy plans ${ }^{27} 263245516466$. Considering the therapy plans of the current work, side effects such as nausea, asthenia, myalgia, arthralgia and abdominal discomfort were not observed throughout the follow-up every 20 days along with treatment until clinical cure. This might be due to the serial plan with 10-day intervals between administrations of $\mathrm{N}$-methylglucamine antimoniate.

Due to the complexity involved in vector-host-parasite interactions, investigators have been faced with different therapeutic choices. No clear consensus exists among the various therapies available in literature ${ }^{911} 132979$ and those presented here. One of the most serious problems is the lack of information regarding daily doses of antimony ${ }^{30455669}$. Our therapy plans are in accordance with maximum daily dose of antimony $(10 \mathrm{~mL}-850 \mathrm{mg} / \mathrm{Sb} /$ day $)$; thus, an intravenous treatment using $20 \mathrm{mg} / \mathrm{kg} /$ day would take $1,400 \mathrm{mg} / \mathrm{Sb} /$ day, or $16.47 \mathrm{~mL}$, for a patient weighing $70 \mathrm{~kg}$, though most investigators do not mention such information.

The results from the patients under study and those from a casuistic of 6,900 cases, since 1965 , provide strong evidence regarding the efficacy of the therapy used here. We have only observed 5 recurrence cases, which is frequently reported when the classic therapy recommended by the $\mathrm{WHO}^{145485054676877}$ is used.

The current work shows the possibility of decreasing antimony volume for ACL treatment, with minimal occurrence of the most likely side effects. It also offers an alternative immunotherapy with promising results for patients, for whom antimony use is not indicated. 


\section{ACKNOWLEDGEMENTS}

We are grateful to the Secretaria Municipal de Saúde of Caratinga and the Consórcio Intermunicipal de Saúde of the Microregião of Caratinga, Minas Gerais State, Brazil, and Mr. Jair Cecílio de Paula for his invaluable support during the field work.

\section{REFERENCES}

1. Aebscher T. Recurrent cutaneous Leishmaniasis: A Role for Persistent Parasites? Parasitology Today 10: 25-28, 1994.

2. Albanese G, Giorgetti P, Santagostinho L, Crippa D, Sala G. Cutaneous leishmaniasis. Treatment with itraconazole. Archives of Dermatology 125: 1540-1542, 1989.

3. Alving CR, Steck EA, Chapman WL JR, Waits VB, Hendricks LD, Swartz GM JR, Hanson WL. Therapy of leishmaniasis: superior efficacies of liposomeencapsulased drugs. Proceedings of the National Academy of Sciences of USA 75: 2959-2963, 1978.

4. Antunes CMF, Mayrink W, Magalhães PA, Costa CA, Melo MN, Dias M, Michalick MS, Williams P, Lima AO, Vieira JB. Controlled field of a vaccine against new world cutaneous leishmaniasis. International Journal Epidemiology 15: 572-580, 1986.

5. Armijos RX, Weiget MM, Aviles H, Maldonado R, Racines J. Field trial a vaccine against new world cutaneous leishmaniasis in at-risk child population: safety, immunogenicity, and efficacy during the first 12 months of follow-up. The Journal of Infectious diseases 177: 1352-1357, 1998.

6. Azeredo-Coutinho RBG, Mendonça SCF. Na intermittent schedule is better than continuous regimen of antimonial therapy for cutaneous leishmaniasis in the municipality of Rio de Janeiro, Brazil. Revista da Sociedade Brasileira Medicina Tropical 35:477-481, 2002.

7. Barral-Netto M, Brodskyn C, Carvalho EM, Barral A. Human leishmaniasis @ cytokines.Bahia.br. Brazilian Journal of Medical and Biological Research 31: 149-155, 1998.

8. Bassiouny A, EL-Meshad M, Talaat M, Kutty K, Metawaa B. Cryosurgery in cutaneous leishmaniasis. Brazilian Journal of Dermatology 107: 467-474, 1982.

9. Belazzoug S, Neal RA. Failure of meglumine antimoniate to cure cutaneous lesions due to Leishmania major in Algeria. Transactions of the Royal Society of Tropical Medicine and Hygiene 80: 670-671, 1986.

10. Bottrel RLA, Dutra WO, Martins FA, Gontijo B, Carvalho E, Barral-Netto M, Barral A, Almeida RP, Mayrink W, Locksley R, Gollob KJ. Flow Cytometric Determination of Cellular Sources and Frequencies of Key CytokineProducing Lymphocytes Directed Against Recombinant LACK and Soluble Leishmania Antigen in Human Cutaneous Leishmaniasis. Infection and Immunity 3232-3239, 2001.

11. Bourée P, Anciaux ML, Taugourdeau. Antimoniate de methyl-glucamine et stibo-gluconate de sodium dans le traitement des leishmanioses. Pathologie Biologue 33: 607-610, 1985.

12. Castes M, Tapia FJ. Immunopathology of American tegumentary leishmaniasis. Acta Científica Venezoelana 49: 42-56, 1998.

13. Chulay JD, Anzeze EM, Koech DK, Bryceson AD. High-dose sodium stibogluconate treatment of cutaneous leishmaniasis in Kenya. Transactions of the Royal Society of Tropical Medicine and Hygiene 77: 717-21, 1983.

14. Convit J, Rondon Ulrich M, Bloom B, Castellanos PL, Pinardi ME, Castes M, Garcia L. Immunotherapy versus Chemotherapy in localized cutaneous leishmaniasis. Lancet 21: 401-404, 1987.

15. Coutinho SG, Da-Cruz AM, Bertho AL, Santiago MA, De-Luca P. Immunologic patterns associated with cure in human American Cutaneous Leishmaniasis. Brazilian Journal of Medical and Biological Research 31: 139-142, 1998.

16. Da-Cruz AM, Conceição-Silva F, Bertho AL, Coutinho SG. Leishmania-reactive CD4+ and CD8 + T cells associated with cure of human cutaneous leishmaniasis. Infection and Immunity 62:2614-2618, 1994.
17. Dan M, Verrer E, el On J, Zuckerman F, Micheli. Failure of oral ketoconazole to cure cutaneous ulcers caused by Leishmania braziliensis. Cutis 38:198199, 1986.

18. El Darouti MA, alRubaie SM. Cutaneous leishmaniasis. Treatment with combined cryotherapy and intralesional Stibogluconate injection. International Journal of Dermatology 29:56-59, 1990.

19. Elloso MM, Scott P. Expression and Contribution of B7-1 (CD80) and B72 (CD86) in the Early Immune Response to Leishmania major Infection. Journal of Immunology 162:6708-6715, 1999.

20. Furtado T. Terapêutica de Leishmaniose Americana - Medicamentos de Escolha. Revista Associação Médica de Minas Gerais 25:108-113, 1974.

21. Furtado TA. An appraisal of Chemotherapy of American Leishmaniasis. Dermatology Ibero Latino Americano III: 2557-2558, 1968.

22. Genaro 0, Toledo VP, Costa CA, Hermeto MV, Afonso LC, Mayrink W. Vaccine for prophylaxis and immunotherapy, Brasil. Clinical Dermatology 14: 503$512,1996$.

23. Gomes LS. A intradermorreação de Montenegro na Leishmaniose e outras pesquisas afins. Brasil-Médico 53: 1079-1087, 1939.

24. Guderian RH, Chico ME, Rogers MD, Pattishall KM, Grogl M, Berman JD. Placebo controlled treatment of Ecuadorian cutâneos leishmaniasis American Journal of Tropical Medicine and Hygiene 45: 92-97, 1991

25. Gundz K, Afsar S, Ayhan S, Kandiloglu AR, Turel A, Filliz EE, Ok UZ. Recidivans cutaneous leishmaniasis unresponsive to lipoma amphotericin B (AmBisone). Journal European Academic Dermatology Venereology 14: 11-13, 2000.

26. Hepburn NC. Cutaneous leishmaniasis. Clinical and Experimental Dermatology 25: 363-370, 2000.

27. Hepburn NC, Siddique I, Howie AF, Beckett GJ, Hayes PC. Hepatoxicity of sodium stibogluconate therapy for American cutaneous leishmaniasis. Transactions of the Royal Society of Tropical Medicine and Hygiene 88: 453-455, 1994.

28. Hermeto MV, Genaro 0, Costa CA, Toledo VPCP, Michalick MSM, Melo MN, Magalhães PA, Resende FS, Dias M, Willians P, Mayrink W. Immunotherapy for American Cutaneous Leishmaniasis in the State of Minas Gerais, Brazil, using Leishvacin ${ }^{\circledR}$.Workshop National sobre Leishmanioses, Recife, Memórias do Instituto Oswaldo Cruz, 1993.

29. Herwaldt BL, Berman JD. Recommendations for treating Leishmaniasis with sodium stibogluconate (Pentostan) and review of pertinent clinical studies. American Journal of Tropical Medicine and Hygiene 46: 296-306, 1992.

30. Koff AB, Rosen T. Treatment of cutaneous leishmaniasis. Journal of American Academic Dermatology 31: 693-708, 1994.

31. Machado-Coelho GLL, Assunção R, Mayrink W, Caiaffa WT. American cutaneous leishmaniasis (LTA) in Southeast Brazil: space-time clustering. International Journal of Epidemiology, Oxford 28: 982-989, 1999.

32. Marovisch MA, Lira R, Shepard M, Fuchs GH, Kruetzer R, Nutman TB, Neva FA. Leishmaniasis recidivans recurrence after 43 years: a clinical and immunologic report after successful treatment. Clinical Infectious Diseases 33: 1076-1079, 2001.

33. Martinez S, Marr JJ. Allopurinol in the treatment of American Cutaneous Leishmaniasis. New England journal of Medicine 326: 741-747, 1992.

34. Mayrink W, Botelho ACC, Michalick MSM, Melo MN, Machado-Coelho GLL Imunoterapia, imunoquioterapia e Quimioterapia no Tratamento da Leishmaniose Tegumentar Americana. VII Reunião Anual de Pesquisa Aplicada em Leishmanioses. Uberaba, MG. Revista da Sociedade Brasileira de Medicina Tropical 35: 122-123, 2002.

35. Mayrink W, Costa CA, Magalhães PA, Melo MN, Dias M, Lima A0. Responses to Montenegro Antigen After Immunization With Killed Leishmania Promastigotes. Transactions of the Royal Society of Tropical Medicine and Hygiene 72: 676-676, 1978.

36. Mayrink W, Costa CA, Magalhães PA, Melo MN, Dias M, Oliveira-Lima A, Michalick MSM, Willians P. A field trial of a vaccine against American Dermal Leishmaniasis. Transactions of the Royal Society of Tropical Medicine and Hygiene 73: 385-387, 1979.

37. Mayrink W, Magalhães PA, Michalick MSM, Costa CA, Lima AO, Melo MN, Toledo VPCP, Nascimento E, Dias M, Genaro 0, Hermeto MV, Williams P. 
Immunoterapy as treatment of American cutaneous leishmaniasis: preliminary studies in Brazil. Parasitologia 34: 159-165, 1992.

38. Mayrink W, Melo MN, Costa CA, Coutinho SG, Hermeto MV, Genaro O, Toledo VPCP, Guerra H. Multinational development of standart skin test antigen in American: preliminary results in the Minas Gerais state, Brazil. 2A. Reunião Anual sobre Pesquisa Básica em Doença de Chagas. Caxambu - MG. Memórias Instituto Oswaldo Cruz 88: 2261993.

39. Mayrink W, Michalick MSM, Melo MN, Nascimento E, Magalhães PA, Costa CA, Oliveira-Lima A, Dias M. Tratamento da Leishmaniose Tegumentar utilizando vacina. Annals Brazilian Dermatology 66: 55-59, 1991.

40. Mayrink W, Resende FS, Costa CA, Hermeto MV, Genaro 0, Toledo VPCR, Michalick MSM, Melo MN, Nascimento E, Willians P, Oliveira-Lima A. Relatório de Atividades no Ambulatório de Leishmaninoses, Caratinga, Minas Gerais, Período1989-1992. Setor de Leishmanioses - Departamento de Parasitologia - Instituto de Ciências Biológicas, Universidade Federal de Minas Gerais, 1993.

41. Melo MN, Mayrink W, Costa CA, Magalhães PA, Dias M, Williams P, Araujo FG, Coelho MV, Batista SM. Padronização do antígeno de Montenegro. Revista Instituto Medicina Tropical de São Paulo 19: 161-164, 1977.

42. Mendonça SC, De Luca PM, Mayrink W, Restom TG, Conceição-Silva F, DaCruz AM, Bertho AL, Da Costa CA, Genaro 0, Toledo VP. Characterization of Human T Lymphocyte-mediated Immune Responses Induced by a Vaccine Against American Tegumentary Leishmaniasis. American Journal Tropical Medicine Hygiene 53: 195-201, 1995.

43. Michalick MSM, Mayrink W, Magalhães PA, Costa CA, Melo MN, Dias M, Willians P, Santos PH. Imunoterapia na leishmaniose tegumentar americana (LTA). In: Resumos do X Congresso da Sociedade Brasileira de Parasitologia, Salvador, BA, p. 119, 1987.

44. Momeni AZ, Aminjaveheri M. Treatment of recurrent cutaneous Leishmaniasis. International Journal of Dermatology 34: 129-133, 1995.

45. Mosman TR, Coffman RL. Th1 and Th2 cells: different functional properties. Annals of Veterinary and Immunology 7:145, 1989.

46. Nadin A. Immunity to Cutaneous Leishmaniasis. Transactions of the Royal Society of Tropical Medicine and Hygiene 78:848, 1984

47. Nascimento E, Mayrink W, Torres FV, Liu TY, Martins MT, Gazzinelli R, Fernandes AP, Genaro 0, Costa CA, Toledo VPCP, Mc Master RW. Enhance Protection In Mice By Vaccination With Combined Parasite Recombinant Antigens (Rgp63 And Rp33) Against Leishmania (Leishmania) amazonensis. XXIII Congresso de Caxambu, MG. Memórias do Instituto Oswaldo Cruz 91: 163-163, 1996.

48. Netto EM, Marsden PD, Llanos-Cuentas EA, Costa JM, Cuba CC, Barreto AC, Badaro R, Jonhson WD, Jones TC. Long-term follow-up of patients with Leishmania (Viannia) braziliensis infection and treated with Glucantime. Transactions of the Royal Society of Tropical Medicine and Hygiene 84:367$370,1990$.

49. Neva FA, Wyler D, Nash T. Cutaneous Leishmaniasis-a case with persistent organisms after treatment in presence of normal immune response. The American Journal of Tropical Medicine and Hygiene 28: 467-471, 1979.

50. Oliveira-Neto MP, Mattos M, Souza CS, Fernandes O, Pirmez C. Leishmaniasis recidiva cutis in New World cutaneous leishmaniasis. International Journal of Dermatology 37: 846-849, 1998.

51. Oliveira-Neto MP, Schubach A, Mattos M, Gonçalves-Costa SC, Pirmez C. Treatment of American Cutaneous Leishmaniasis: a comparation between low dosage $(5 \mathrm{mg} / \mathrm{kg} /$ peso and high dosage $(20 \mathrm{mg} / \mathrm{kg} /$ day $)$ antimony regimens. Pathologie Biologue 45: 496-499, 1997.

52. Oster CN, Chulay JD, Hendricks LD, Pamplin CL $3^{\text {rd }}$, Ballou WR, Berman JD, Takafuji ET, Tramont EC, Canfield CJ. American cutaneous leishmaniasis: a comparison of three sodium stibogluconate treatment schedules. The American Journal of Tropical Medicine and Hygiene 34: 856-860, 1985.

53. Palacios R, Osorio LE, Gralalew LF, Ochoa MT, Treatment failure in children in a randomized clinical trial with 10 and 20 days of meglumine antimoniate for cutaneous leishmanisasis due to Leishmania viannia species. The American Journal of Tropical Medicine and Hygiene 64: 187-193, 2001.

54. Passos VMA, Barreto SM, Romanha AJ, Krettli AU, Volpini AC, Costa MFFL. American cutaneous leishmaniasis: use of a skin test as a predictor of relapse after treatment. World Health Organization 78: 968-974, 2000.
55. Pessoa SB, Pestana BR. A intradermo-reação de Montenegro nas campanhas sanitárias contra a Leishmaniose. Arquivos de Higiene e Saúde Pública 6:124-137 1941.

56. Pirmez C, Fernandes 0, Oliveira-Neto MP. A reação em cadeia da polimerase (PCR) antes e após tratamento na leishmaniose tegumentar. Revista da Sociedade Brasileira Medicina Tropical 33:58-59, 2000.

57. Ramírez JL, Guevara P. Persistent Infections by Leishmania (Viannia) braziliensis. Memórias Instituto Oswaldo Cruz 92: 333-338, 1997.

58. Reed SG, Scott P. T-cell and cytokine responses in leishmaniasis. Current Opinion in Immunology 5:524-531, 1993.

59. Ribeiro-de-Jesus A, Almeida RP, Lessa H, Bacellar O, Carvalho EM. Cytokine profile and pathology in human leishmaniasis. Brazilian Journal of Medical and Biological Research 31:143-148, 1998.

60. Rodriguez ME, In Guanzo P, Ramos A, Perez J. Treatment of cutaneous leishmaniasis with $\mathrm{Co}_{2}$ lazer radiation. Revista Cubana Medicina Tropical 42:197-202, 1990

61. Romero GA, Guerra MV, Paes MG, Macedo VO. Comparation of cutaneous leishmaniasis due to Leishmania (Viannia) braziliensis and L. (V.) guyanensis in Brazil: therapeutic response to meglumine antimoniate. The American Journal of Tropical Medicine and Hygiene 65: 456-465, 2001.

62. Row R. Curative value of Leishmania culture vaccine in Oriental sore. Brazilian Medical Journal 9:540-541, 1912.

63. Rzany B, Krutmann J, Goerttler E, Schopf E. Cutaneous leishmaniasis: treatment with cryotherapy and intramuscular injections of Meglumine Antimoniate (Glucantime®). Hautarzt 41:98-101, 1990

64. Saenz RE, Narváez E. Evaluation of the effectiveness and toxicity of Pentostan and Glucantime in the treatment of cutaneous leishmaniasis. Revista Medica do Panamá 12:148-157, 1987.

65. Saenz RE, Paz H, Berman JD. Efficacy of Ketoconazole against Leishmania braziliensis panamensis cutaneous leishmaniasis. American Journal of Medicine 89: 147-155, 1990.

66. Saldanha ACR, Romero GAS, Hamann EM, Magalhães AV, Macedo VO. Estudo comparativo entre estibogluconato de sódio BP 88R e antimoniato de meglumina no tratamento da leishmaniose cutânea: I. Eficácia e segurança. Revista da Sociedade Brasileira Medicina Tropical 32: 383-387, 1999.

67. Saravia NG, Weigle K, Segura I, Giannini SH, Pacheco R, Labrada LA, Goncalves A. Recurrent lesions in human Leishmania braziliensis infection - reinfection? Lancet. 18: 398-402, 1990.

68. Schewach-Millet M, Fisher BK, Semanh D. Leishmaniasis recidivans treated with sodium stibogluconate. Cutis 28: 67-68, 1984.

69. Schubach A, Marzochi MC, Cuzzi-Maya T, Oliveira AV, Araujo ML, Oliveira AL, Pacheco RS, Momen H, Conceicao-Silva F, Coutinho SG, Marzochi KB. Cutaneous Scars in American Tegumentary Leishmaniasis patients: a site of Leishmania (Viannia) braziliensis persistence and viability eleven years after antimonial Therapy and clinical cure. American Journal of Tropical Medicine and Hygiene 58: 824-827, 1998.

70. Sharquie KE, Al-Talib KK, Chu AC. Intralesional therapy of cutaneous leishmaniasis with sodium stibogluconate antimony. Brazilian Journal Dermatology 119: 53-57, 1988.

71. Silveira FT, Mayrink W. Leishmaniose Cutânea difusa no Estado do Pará, Brasil: Registro do primeiro caso de cura da doença após associação de quimioterapia com imunoterapia. XXIX Congresso da Sociedade Brasileira de Medicina Tropical. Revista da Sociedade Brasileira de Medicina Tropical 26 (supl):229, 1993.

72. Silveira FT, Mayrink W. Leishmaniose Cutâneo-Difusa No Estado do Pará, Brasil: Relato da Cura de Um Caso Depois de 24 Anos de Doença, Após Tratamento Combinado de Quimioterapia com Imunoterapia. In: Anais do XXXIII Congresso da Sociedade Brasileira de Medicina Tropical, p.129, 1997.

73. Snedecor GW, Cochran WG. Statistical Methods, $8^{\text {th }}$ edition. Iowa State University Press, Ames, Owa, 1989.

74. Soto-Mancipe J, Grogl M, Berman JD. Evaluation of pentamidine for the treatment of cutaneous leishmaniasis in Colombia. Clinical Infectious Diseases 16: 417-425, 1993 
75. Tapia FJ, Dittamar GS, Sánchez MA. Inadequate epidermal homing leads to tissue damage in human cutaneous leishmaniasis. Immunology Today 5:160-165, 1994.

76. Vianna G. Tratamento da leishmaniose tegumentar por injeções intravenosas de tártaro emético.In: Anais do $7^{\circ}$ Congresso Brasileiro de Medicina e Cirurgia 4: 426-428, 1912.

77. Weigle KA, Valderrama L, Santrich C, Saraiva NG. Recurrences of Tegumentary Leishmaniasis. Lancet 2:557-558, 1985.
78. World Health Organization - Division of Control of Tropical Diseases. Statistics as of April 1998. Apud: Kenner JR, Aronson NE, Bratthauer GL, Turnicky RP, Jackson JE, Tang DB, Sau P. Immunohistochemistry to identify Leishmania parasites in fixed tissues. Journal of Cutaneous Pathology 26:130-136, 1999.

79. Wortmann G, Miller SR, Oster C, Jackson J, Aronson N. A Randomized, Double-blind Study of the Efficacy of a 10- or 20- Day Course of Sodium Stibogluconate for Treatment of Cutaneous Leishmaniasis in United States Military Personnel CID 35: 261-267, 2002. 